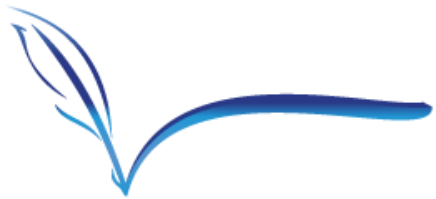

SSAD

Stratejik ve Sosyal Araştırmalar Dergisi

ISSN 2587-2621

Volume 5 Issue 2, July 2021

sisaddergi@gmail.com

Makale Türü/Article Type: Araştırma/Research

Makale Gönderim Tarihi/Received Date: 31.05.2021

Makale Kabul Tarihi/Accepted Date: 22.06.2021

DOI: $10.30692 /$ sisad. 945448

\title{
BAȘLANGIÇTAN RÖNESANS'A AŞAĞI VE YÜCE BİR MESLEK: OYUNCULUK
}

\author{
Low and Lofty Profession Acting, from the Beginning to Renaissance \\ Erdal YILDIRIM
}

Dr.

Kartal Belediye Tiyatrosu Genel Sanat Yönetmeni

ORCID ID: 0000-0002-6315-4563

ey20162019@gmail.com

\begin{abstract}
Atıf/Citation: Erdal Yıldırım (2021), "Başlangıçtan Rönesans’a Aşağı ve Yüce Bir Meslek: Oyunculuk”, Stratejik ve Sosyal Araştırmalar Dergisi, C.5, S.2 Temmuz 2021 s.407-422.
\end{abstract}

Öz: Oyun, insandan önce var olan bir olgudur. İlkel ya da modern insan, hayatının birçok yerinde oyun eylemine başvurmuştur. Aslında her insan birer oyuncudur. Eylem olan oyunun sanat olarak oyunculuğa dönüşmesiyle birlikte, öznesi ve nesnesi insan olan bu sanat, toplumla kurduğu dolayımsız bağ ve gerçeği yansıtma mottosuyla, insana en yakın ve en popüler sanat olma konumuna erişmiştir. Popüler bir sanat olması, birçok aktörün ya da aktrisin çok geniş kitlelerce beğenilmesi, gençlerin bir gün keşfedilip yıldız olma hayalini kurması, tiyatroda ya da ekranlarda oyuncuları görebilmek için salonların dolması, bu sanat hakkında bilinenlerle doğru orantılı bir episteme değildir. Dışarıdan en az bilinen bir meslektir oyunculuk. Kendi iç dinamikleri içinde icrası zor, meşakkatli ve çok fazla özveri isteyen bir sanat koludur. Bu makalede oyunculuk sanatının ontolojisi, var olabilme mücadelesi, başlangıcından Rönesans'a değer ve mesleki itibar noktasında inişli çıkışlı, daha çok inişli bir grafiğe sahip olmasına rağmen, yersiz ve yurtsuz bir şekilde varlığını idame ettirebilme süreci oyun-yaşam ilintisi bağlamında incelenecektir.

Anahtar Kelimeler: Antik Yunan ve Roma, Oyunculuk, Tiyatro, Ortaçağ, Rönesans.

\begin{abstract}
Acting is a phenomenon, that exist even before humanbeing. Both troglodyte and modern person use acting in most parts of their lives. In fact, each individual is an actor. After turning into art, acting, which has person as a subject and object, get to be the closest art to person and the most popular one. Thanks to having a direct connection with community and a motto of reflecting the reality. Acting is a popular art, many actors and actresses are admired by large masses, young ones wish to be noticed and be popular, people fill the halls just to see the actors and actresses. All these are not directly proportional to the fact of this art. Acting is the least known occupation from outside. Within its own internal dinamics, it is hard to execute branch of art that needs so much devotion. In this article; ontology of acting art and its struggle for existence will be analysed. And also from the beggining to the renaissance - despite having a bumpy chat on the point of value and proffessional reputation- the process of continuing existance in an autlandish way will be studied in the context of act-life relation.
\end{abstract}

Keywords:, Ancient Greek And Rome, Acting, Theater, Medieval Age, Renaissance. 


\section{GİRIŞ}

Oyun, insanlık tarihi boyunca prehistorik dönemden günümüze bir eylem olarak hep var olmuştur. Her çağda insan, insan olduğunu oyun eylemiyle göstermiş ve var olma biçimi olarak bu eylemi gerçekleştirmiştir. Schiller'e göre insan oynayan bir varlıktır ve oynaması tam bir insanlık göstergesidir. (Schiller, 1990, s.76). Fakat oyun sadece insana mahsus bir eylem değildir. Hayvanlar da oynamaktadır. Huizinga o nedenle oyunu kültürden eski bir olgu olarak değerlendirmektedir (2013, s.20). Çünkü ona göre insanlar olmadan da oyun vardı. Ve hayvanlar bu eylemi öğretmesi için insanı beklememiştir.

İnsanoğlunu diğer canlılardan ayıran imgesel düşünme yeteneği ve yaratma gücü, oyun eylemini daha ileri götürmesine ve bir yaşam biçimi kurmasına olanak sağlamıștır. Örneğin ilkel insanın ava çıkmadan önce av dansı yaparak avlanacak avı büyü yoluyla etkilemeye çalışması ve bunu bir toplu gösteri şeklinde izleyicilerle birlikte ifa etmesi, profesyonel manada bir tiyatro oyununu ve seyirciyi andırmaktadır. Toplumsal anlamda bu büyü dansı, dansa katılanları daha av başlamadan psikolojik ve fiziksel yönden hazırlamakta, "toplumsal eğitim aracı olarak gerek fiziki ve mesleki, gerekse etik ve estetik eğitim aracı olarak işlev görmektedir." (Kagan, 1982, s.240). Ernst Fischer av dansinın bu oyunsu tarafinın, hem topluma hem de avciya güven duygusu verdiğini, doğaya karşı bir var olma savaşı anlamına geldiğini ve ilkel insanın sanatı yaratma gücünü arttırdığını söylemektedir (2017, s.52). Diğer anlamda da bu büyü oyunları, toplumsallığın pekişmesi ve insanın kendisini ikna etmesiyle isteklerinin gerçekleşmesini sağlamaktadır. "Bu iç gụ̈c onun 'daimon'ludur. Daimo'un özelliği kolektif olarak ortaya çıkarılması ve yine kolektif olarak duyumsanmasıdır." (Andiç, 2019, s.36, 37).

İlkel insanın kendince bir mücadele içine girmesi yani doğaya karşı var olduğunu göstermesi, bu durumu da gerek büyü yoluyla gerekse doğa koşullarına paralel bir şekilde kendini konumlandırarak yapmaya çalışması ve bunun bilincine varması oyun yönünün gelişmesini de beraberinde getirmiştir. Temel yaşamsal ihtiyaçları karşılayabilen insanoğlu yaşadığı tüm gelişmeleri çeşitli sesler, danslar, gösterilerle dile getirerek duygularını ve düşüncelerini ifade etmiştir. $\mathrm{Bu}$ ilkel oyunlar zamanla belirginleşip düzenli bir hal alarak ritüele, dinsel tören aşamasına dönüşmüştür. (Yıldırım, 2021, s.17). Diğer taraftan vakit geçirmek ve eğlenmek için de oyunlar oynayan homo ludens (Huizinga, 2013, s.16) (oynayan insan), oyunlar sayesinde bir yaşam biçimi olarak varlığını göstermenin belirgin bir yöntemini hayatının merkezine yerleştirmiştir. Homo, oyun eylemiyle döngüsel yaşamı keşfi sonucunda, araç durumundan, toplumsal bir iletişim dili kuran birey-toplum ağının oluşumuna katkı sağlamıştır. (Tekerek, 2006, s.47). Ve genel görüşe göre Dionysos kültünden tiyatronun doğuşuyla birlikte eylem olarak oyun ifası sanat olarak oyunculuk mesleğine dönüşmüştür. Zaten insan hayatının her safhasında yer alması, öznesi ve nesnesinin insan olması hem icracilık anlamında hem de seyirci katında bu mesleğin ününü ve cazibesini arttırmıştır. Fakat meslek olarak paradoksal bir şekilde her zaman tartışmaların odağında yer almış, üstün değerler atfedilirken, en aşağı iş kolu olarak ta konumlandırılmıştır.

Oyunculuk, aslında sanatlar içinde en az bilinen bir meslek koludur. Popüler bir sanat olması, birçok aktörün ya da aktrisin çok geniş kitlelerce beğenilmesi, gençlerin bir gün keşfedilip yıldız olma hayalini kurması, tiyatroda ya da ekranlarda oyuncuları görebilmek için salonların dolması bu sanat hakkında bilinenlerle doğru orantılı bir episteme değildir. Dışarıdan en az bilinen bir meslektir oyunculuk. Birçok insan, bir ressamın nasıl resim yaptığına, bir müzisyenin nasıl prova aldığına, bir roman yazarının nasıl yazdığına dair oldukça doğru fikre sahip olmasına karşın, bir aktörün nasıl role hazırlandığına dair pek fazla fikre sahip değildir. Bu durum genel değerlendirmelerle geçiştirilmiş, bilgi doğruluğu gizini hep korumuştur. Yapılan

${ }^{1}$ Terim Yunan Tradisyonunda üç anlamda kullanılır. 1) İnsanları yöneten ve geliştiren yüce varlıklar. 2) Vicdan. 3) Düşünce formları. Bu terim daha sonra Avrupa'da Demon sözcügüne dönüşmüş ve Şeytanı tanımlamak için kullanılmıştır. 
genel değerlendirmeler iki başlık altında toplanabilir: Mistik bir bakış açısıyla Allah vergisi; rasyonalist bakış açısıyla tamamen akıl işi. Aslında iki yaklaşım da oyunculuğu sanat olmaktan koparan değerlendirmelerdir. Mistik bakış açısı bu sanatı doğaüstü bir gizem olarak değerlendirirken, rasyonalist bakış açısı fazlasıyla estetize eden bir yaklaşıma sahiptir. Yaygın bu iki fikir perspektifinde bakıldığında oyunculuk, eğitimle ilintili olmayan, güzel bir yüz, mikrofonik bir ses, mükemmel bir vücut gibi bariz dış nitelik ve yaratılış meselesi olarak görülmektedir (Hornby, 1983, s.19). Fakat oyunculuk tarihine bakıldı̆̆ında fiziksel görünümü bahsedildiği gibi güzel olmayan birçok başarılı oyuncuya rastlanılmaktadır.

Oyunculuk, kendi iç dinamikleri içinde yapılması zor ve çok fazla özveri isteyen bir meslek kolu olsa da, insanlık tarihinin her döneminde varlığını, popülerliğini, gücünü korumuş; fakat mesleki anlamda gereken değeri bulamamış yersiz ve yurtsuz bir şekilde varlığını idame ettirmiştir. Yani Oyunculuk, tarihsel olarak değer ve mesleki itibar noktasında inişli çıkışlı daha çok inişli bir grafiğe sahip bir iş kolu olmasına rağmen, insanlık tarihinin her döneminde popüler bir sanat olmayı başarmıştır.

\section{Antik Yunan ve Roma'da Oyunculuk}

Antik Yunan tiyatrosunda oyunculara hipokritler denilmektedir. Bunlar aynı zamanda ilk profesyonel oyunculardır. (Schyberg \& Carlson, 1961, s.68). Yani sahnede repliği olan söz söyleyen kişilerdir. Zaten hypokrites kelimesi etimolojik olarak yanıtlayan anlamına gelmektedir. Oyun içinde yer alan koro ve çeşitli rollere figüran olarak çıkan kişiler oyuncu/hypokrites olarak görülmemektedir. Onlar yanıtlayan konumunda değillerdir. Koroya, choregus (korobaşı) karar verir ve ücretlerinin ödenmesi de korobaşı tarafından yapılmaktadır. Gösterilerde koro, oyuncular gibi yukarı sahnede değil, orkestrada durmaktadır. Oyuncuların durumu ve konumu farklıdır. Onları devlet işe almakta ve ödemeleri de devlet tarafından yapılmaktadır. (Haigh, 1889, s.197).

Oyunculuk mesleğine bakışın bir iz düşümü olarak, antik dönemde Platon'un sanat karşıtlığı çerçevesinde mimetik yaratım tümden reddedilmektedir. Daha en başından Platon'un en temel karşı çıkış noktası şairlerin, tanrılar ve insanlar hakkında yalanlar anlatıyor olması ve tutkuları körüklemesidir. Devlet’teki şikâyetlerinden ilki de budur. Ona göre duyularla algılanan nesneler gerçeği yansıtmamaktadır. Onlar sadece gerçekliğin ideal biçiminin kopyalarıdır. Yani bu şekliyle sanatçı, ikincil biçimi kopyalayarak gerçekten uzaklaşmaktadır. Ona göre gerçek sanatçı, gerçekle iştigal eder, kopya ile değil. Platon'un bu eleştirel yaklaşımı sanat-hayat iliş̧kisini ilk kez ortaya koymaktadır. Platon bir anahtar sözcük olarak günümüze değin gelen mimesis (taklit) kavramını, bu ilişkiyi anlatmak için ilk kez kullanmıştır. Ona göre bu terim alçaltıcıdır. Aristoteles ise mimesis'e olumlu bir işlev yüklemiş, bu terime itibar kazandırmıştır. (Carlson, 2007, s.17). "Platon'a göre şairler zaten doğada kutsal olarak bulunan yaratıcı etkinliği kopya etmektedir. Aristoteles'e göre ise sanal olarak mimesis, yaratıcı bir etkinliktir." (Nutku, 2001, s.35). Platon'a göre kopyalanan, gerçeğin kopyasıdır, gerçek değildir. Arsitoteles göre ise sanatçı, taklitle (yeni bir sanalla) gerçeği yeniden yaratmaktadır. Platon "Devlet" adlı eserinde 10. bölümünde taklitle şiirin coşkuyu beslediğini heyecan duygusunu çoğalttığını, bunun da kuşkuya sebep olduğunu, o nedenle şiiri ve onun en iyi ifade edildiği dram sanatını (tiyatroyu) reddetmektedir. Ona göre şair sözlerini süsleyerek insanları etkilemekte tutkuları köreltmektedir. Ve aslında "şairlerin yarattı̆̆ birer gölgedir, gerçek varlıklar değildir". (Platon, 1999, s.340).

Platon'un tiyatro için tutkuları körüklediği iddiası karşın, Aristoteles Yunan tıbbi terimi olan katharsis'ten bahsederek tragedyanın tam tersine seyirciyi bu tür duygulardan arındırdığını ileri sürmektedir. Tragedyalarla verilen acıma ve korku duyguları homeopatik ${ }^{2}$ ilaç işlevi görmektedir. Ve bu da taklit yoluyla sağlanmaktır. Aristoteles'e göre tüm sanatların kaynağ

\footnotetext{
${ }^{2}$ Hastalığa sebebi olan etmenlerin belirli dozlara hastaya verilmesiyle tedavi edilmesidir.
} 
taklittir. Fakat taklit bir birebir kopyalama değil belirli ölçütlerde yansıtmadır. (Aristoteles, 1987, s.43). "Ozanlar, ya ortalama insandan daha iyi ya da daha kötü olanlarl yahut da ortalama insanların eylemlerini taklit ederler. Aynı şeyi ressamlarda da buluyoruz: Polygnotos daha iyileri, Pauson daha kötüleri, Dionysios ise gerçeğe uygun olan kişileri taklit etmeye çalışmışlardır." (Aristoteles,1987, s.13). Gerald Else, Platon'dan Aristoteles'e geçişi, kopyalamadan yaratmaya geçiş olarak açıklamaktadır. (aktaran Carlson, 2007, s.17). Yani "taklit, temsil etme ya da bir bakıma yeniden yaratım, günümüz anlayışında ise yanılsama kategorisinde ilintilidir." (Çalışar, 1995, s.43).

Bu kadim sanatın en önemli bileşeni olan oyuncu da daha en başından çok ciddi eleştirilere ve karşı çıkışlara maruz kalmıştır. Bu kişinin ilk oyuncu olması ve bu denli olumsuz tepkilere maruz kalması, oyunculuk mesleğinin devamında nasıl bir seyir izleyeceğinin bir göstergesi olarak okunabilir. Birçok kült olmasına karşın genel görüşe göre tiyatro, dionysos kültünden doğmuştur. Yunanlıların şarap ve bereket tanrısı Dionysos onuruna söylenen ditramboslar ve ritüel danslar bu sahne sanatının filizlendirmiş ve ortaya çıkmasını sağlamıştır. İsmi günümüze değin gelen ve çağlar boyu zikredilen, koronun karşına bir oyuncu koyan, monologdan diyaloga geçişi sağlayan, entrikayı, mizanseni bu sanata katan ilk oyuncu Thespis'tir. (Haigh, 1889, s. 198,199). Aynı zamanda yazar da olan Thespis Atina'da sahnelediği, kendisinin de rol aldığ oyunlarından birinde Solon tarafindan aldatıcı ve tehlikeli kişileştirilmeler yapmakla suçlanmış ve böyle bir suç isnat edilen ilk oyuncu olmuştur. Yasa koyucunun, oyunculuğu bu şekilde kötü eleştirmesinin sebebi, gerçekliğin bir yanılsama yaratılarak, seyirciyi gerçek olmayana inandırabilme endişesinden kaynaklanmaktadır. $\mathrm{O}$ nedenle bilinen oyunculuk tarihinden beri gerçeklik ve yanılması, bu sanatının hep odağında ve tartışmaların merkezinde yer almıştır. (Carter, 2011, s.14).

Tiyatro sanatının doğuşundan sonra çeşitli aşamalarla oyunculuk sanatı gelişim göstermiştir. Oyuncu ve yazarın aynı kişi olması zamanla terkedilmiş; hem nicel hem değer anlamında gelişmeler, hem de yazarlıktan ayrılarak mesleki anlamda konumlanışı, bu sanatın önemini attırmıştır. Aristoteles'e göre Aiskhylos ikinci oyuncuyu, Sofokles ise üçüncü oyuncuyu eklemiştir. (Thomson, 1990, s.208). Ve 449'lu y1llarda oyunculuk, yazarlıktan tamamen ayrılmıştır. Genel görüşe göre 4. yüzyılda meslek haline gelmiştir. Yunan'da aktörler komedya ya da tragedya türlerinden birini seçerek aktörlük yapmaktadır. Önemli olan oyunculuk mesleğidir. Ve sahnelenen temsildir. $O$ nedenle bir tiyatro topluluğu için oyuncunun tanınırlığının çok önemi yoktur. Roma'da ise bu yaklaşımın değiştiği görülmektedir. Oyuncu hem tragedya hem komedya alanında icra yapabilir ya da herhangi birinde uzmanlaşma yolunu tercih edebilir. Topluluktaki yıldız oyuncu temsilden ve diğer oyunculardan daha değerli görülür. (Yıldırım, 2013, s.47). Oyuncunun palazlanması bir takım özelliklerinin gelişmesi gerektiği gerçeğini ortaya koymuştur. Bunlardan ilki ses yetisidir. Ses tonunun güzelliğin yanı sıra, karaktere uygun duygu ile konuşmak ve büyük amfilerde sesi duyurabilmek birincil öneme haizdir. Yani temsillerde "konuşma, resitatif ve şark" (Brockett, 2000, s.36) en önemli özelliklerdir. $\mathrm{Bu}$ özelliklere sahip sanatçı Yunan toplumunda ayrıcalıklı bir konuma erişmektedir. Ve artık yazarlardan da önce gelmektedirler. Aristoteles'de kendi dönemi için oyuncuların yazarlara oranla daha fazla önemsendiğinden söz etmektedir. Oyuncuların devlet tarafından çeşitli görevlere getirilmesi değer anlamındaki bakış açısının göstergelerindendir. Örneğin tragedya oyuncularından Aristodemus'u Yunan Devleti iki kez elçi olarak Makedonya'ya göndermiştir. (Nutku, 1995, s.27). Devlet ve toplum nazarında dini misyonu olan Dionysos'un hizmetkârı oyuncular askerlik vazifesinden de muaf tutulmuşlardır. (Karg1, 1991, s.15).

Antik Yunan'da tiyatronun/oyunculuğun bu denli önemsenmesinin sebebi dramanın hayatın bir parçası olarak görülmesinden kaynaklanmaktadır. Devlet de bu bağı bildiği için bütçe ayırarak çeşitli festivaller yapılmasına katkı sağlamak suretiyle halkın tiyatroya gitmesini teşvik etmektedir. Sahnelerin, ibadethanelerin yanına yapılması tiyatroya dini bir misyon da yüklemektedir. $\mathrm{Bu}$ durum Yunanlılar için dramanın hayatlarındaki yeri ve önemi yansıtması 
bakımından önemli bir göstergedir. Ayrıca dügünler ve cenazeler de tiyatral bir gösterim şeklinde yapılmaktadır. Tanrının kült imajının yerleştirildiği tapınaklar ve yapılan geçit törenleri de rahipler tarafından tiyatral bir şekilde ifa edilmektedir. Tüm bunların açık havada olması, Yunanistan'da yağmur ve kar yağışının ender görülmesinden kaynaklanmaktadır. O nedenle de düzenlenen hayata dair her kutlama ya da tören, geniş kitlelere hitap etmektedir. "Yunan kültürünün her alanında, icrada doğa nosyonları da vardı. Bu durum Yunanlılar için samimiyet anlamında dramaya bağlılığın bir nedeni olabilir." (Bamunusinghe, 2012, s.79,80). Ayrıca dramaları desteklemek çok önemli bir prestij olarak görülmektedir. Özellikle Dionysos festivallerinde oyunları finanse etmek paha biçilmez bir onurdur. Oyunları himaye eden bu zengin kişilere 'khoregos' denilmektedir. Aristokrat himayenin bir unsuru olan ve bu görevi üstlenen kişiye saygiyla bakılır ve toplumda ayrı bir önem görürdü. (Freeman, 2003, s.258). Böylesi önemsenen ve maddi destekçisine saygınlık kazandıran drama da, icracısı oyuncu da Yunan toplumunda muteber bir konuma sahiptir.

Antik Yunan'da saygın bir meslek olan oyunculuk Roma'da aşağılık bir uğraş olarak görülmekteydi. Bahsedildiği üzere Antik Yunan'da oyuncular iyi eğitim görüyorlar ve itibarlı bir konumdaydılar. "Tanrı Dionysos'un rahipleri olarak görülüyorlardı." (Nutku, 1995, s.32). Tiyatronun başlangıcı olan dionysos şenliklerinde bir esrik, büyülenme ile insanlar "kendini satir olarak görür, satir olarak tanriya bakarlardı". (Nietzsche, 2019, s.53). Roma'da ise oyunculuk köleler için uygun bir meslekti. Eğitim almaları söz konusu değildi. Diksiyon eğitimi almadıkları için kaba hareketlere dayalı bir icra biçimi söz konusuydu. Yani "Yunanistan'da oyunculuk ritüelistik bir yücelik taşırken, Roma'da oyuncu eğlencelik sayılıyordu." (Nutku, 1995, s.32). Yani Roma'da oyunculuğun ne bir dinsel karşılığı, ne de devlet tarafından desteği söz konusuydu. Bu mesleği icra edenlerin çoğunu, okuma yazması olmayan kaba saba insanlar oluşturmaktaydı. Kendisine saygısı olan kentli insanların tercih etmeyeceği çok avam bir meslek olarak görülmekteydi. Oysa Yunanistan'da üst rütbeli subaylığa ve elçiliğe atanmış oyuncular mevcuttur. Sofokles'te bu minvalde general olarak atanmıştır.

Roma'da oyunculuğun bu denli özensiz ve önemsiz olmasının bir sebebi de alımlayıcı olan halkın beğeni düzeyidir. Roma İmparatorluğu kurulmadan önce Satura denilen bir komedi tiyatro biçimi vardı. İtalya'da bu yaygın oyun biçimi halk tarafindan çok seviliyordu. Kökeni Demeter kültürüne dayanan bu oyun yapısı kaba ve basit güldürüye sahip temsillerdi. Saturanın Tarım tanrıçası Demeter için düzenlenen törenlerde okunan şiir ve komik oyunların birleşiminden doğduğu düşünülmektedir. Bu komik oyunlar Etrüksler tarafından keşfedilmiştir. Romalılar dilini anlamadıkları bu gösterilere, kaba hareketlerle icra edildiğinden dolayı rağbet göstermiştir. Daha sonra İ.Ö 474'de Ludi oyunlarında Saturalara yer vermişlerdir. (Karg1, 1991, s.18). Öncesinden de anlaşılacağ 1 üzere genelde biçimsellikten, kaba güldürülerden, gladyatör dövüşlerinden hoşlanan bir halk yapısı söz konusudur. O nedenle sahnelenen oyunlar bu minvalde özellikler taşımaktaydı. Roma'da Yunan oyunlarının kontrollü yapısı yerine spektaküler gösteriler tercih ediliyordu. Cicero'nun "Clytenmestra" oyununda sahneye 600 katırı soktuğundan söz edilmektedir. Bir diğer örnek te Terentius "Kaynana" adlı oyunun proloğunda yazdığ 1 , ilk oyunda seyircilerin yer kavgası yapıp kavga ettikten sonra ikinci perdede gladyatör dövüşü seyretmek için kaçmasıdır. Gladyatör dövüşleri zamanla öyle bir hal almıştır ki, bir güç gösterisine dönüşmüş, bu işin görsel olarak ününü arttırmıştır. Genel görüşe göre ölen kişin ardından düzenlenen bu oyun, "Roma Cumhuriyet Dönemi'nin sonlarına doğru, ölü kültünden ziyade profan bir eğlence ve gösteri organizasyonuna dönüşmüştür." (Uzunaslan, 2005, s.19). Yani çok fazla rağbet gören "ölümle sonuçlanan kanl gösteriler, başlangıçta kölelere ve esirlere bir cezalandırma biçimi ve bir kurban ritüeliydi." (Karakoç, 2015, s.155). $\mathrm{Bu}$ perspektifte oluşan seyirci davranışı tiyatro oyunlarına da doğal olarak sirayet etmişti. Oyunlara eğlenmek için gelen kitleyi kontrol etmek, rolünü icra eden oyuncu için çok önemli bir meziyet haline gelmiş, hatta rolünden de bir adım öteye geçmiştir. Çükü sürekli müdahale eden bir seyirciyi dizginlemek, oyunculuk yeteneğinin dışında başka hünerler de gerektirmektedir. O dönem oyuncusu için bu durum ayrı bir yük ve ayrı bir sorumluluktur. 
Böylesi bir topluluk karşısında başarının, oyuncunun kitleyi kontrol edebilme yeteneğine de bağlı olduğu görülmektedir. "Trentius usta oyuncuların oyunu başarılı kllıp değersiz bir oyuna seyircinin paye verebildiğini gözlemlemiştir." (Trentius, 1946, s.1). Böylesi bir atmosfer karşısında oyunculuk icra etmek yasal ve dinsel haklardan mahrum, günü kurtarmaya çalışan kölelere kalıyordu. Onlar da sahipleri tarafından yönlendiriliyordu. Öyle ki Plautus "Çömlek" adlı oyununun önsözünde anlattığına göre hata yapan oyunculara dayak atılır, hata yapmayanlara da içki verilirdi. Onlar sadece halkı eğlendiren bir basit eğlendiricilerdir. (Cole \& Chinoy, 1997, s.33,31) Oyuncuların icra ettiği oyunlar sadece ticari nitelik taşıyan bir gösteriden ibarettir. (Çalışlar, 1995, s.30).

Oyunculuk mesleğine sirayet etmiş bu olumsuz leke ve onun sefil icracısı köleler, oyunlarda bile aşağılık damgası yemekteydiler. Plautus'un "Amphitrio" oyununda bu durum seyirciden özür dilemek maksadıyla şu şekilde anlatılmaktadır:

"Krallar, Tanrılar çıkacak bir oyunu başından sonuna kadar komedya etmek bence hiç yakışık almaz ama ne yapalım, içinde bir köle var, onun için, demin de dediğim gibi yart tragedya ederim, yarı komedya. (aktaran Şener, 2003, s.57).

Roma'da oyunculara öyle bir bakış açısı hâkimdi ki, köleler ve fahişelerle aynı kategoride görülmekteydiler. Özgür doğanlar eğer oyuncu ise vatandaşlık hakkını kaybediyordu. Onların ifade özgürlüğü yoktu. Ve daha da ileri gidilerek özgür vatandaşlar bir oyuncuyu mahkemeye hesap vermeden öldürebilirdi. (Schyberg \& Carlson, 1961, s.68). Bu sosyolojik davranışın altında kodlanmış Roma anlayışı yatmaktadır. Egon Friedell'a göre Romalı insanlar ticarette ve siyasette her türlü kurnazlıktan, kandırmacadan nefret eden bir yapıya sahiptir (1999, s.49). Romalılar nezdinde bu tür davranışlar kölelere ve fahişelere özgü meziyetlerdir. Bilim ve sanatla ilgili her şey edepsizlik sayıldığından, bu mesleklerle iştigal eden insanlar da genelde edepsiz sayılan kişilerdi. Romalıların bu yaklaşımı sanatın ve bilimin pratik gündelik yaşama etki etmemesinden kaynaklanmaktadır. Zaten Latincede scriba (yazar) sözcüğü mevcutken, poeta (şair) sözcüğü ödünç alınmıştır. Dolayısıyla pratik yaşama katkı sağlamayan her türlü tinsel, artes leviores (önemsiz sanat), studia minora (ikinci derecede) uğraşlar sayılırdı. "Roma sanatının en tipik özelliği pratik bir yarar sağlama işleviyle yapılmasıdır. Yontular, yapılar, oyunlar hem bu çerçevede uygulanmıştır." (Şener, 2003, s.55).

Roma devletinin kodlarında bir güç gösterisi söz konusudur. Çünkü Roma devleti savaş̧̧ı ve işgalci bir yapıya sahip köleleştirme mottosuyla topraklarını genişleten bir yapı arz etmektedir. Etraftaki küçük kentleri alarak zamanla tüm İtalya'ya hâkimiyet kurmuştur. Zorunlu bir sonuç olarak böyle bir yapı içerisinde birincil öneme haiz özellik iyi savaşçı olabilmektir. Bu perspektifte sanatta sadece eğlendirici ve oyalayıcı olmalıdır. Nitekim Ludi diye adlandırılan tiyatro şenliklerine bile bu vahşi yapı hâkimdi. Başlangıçta spor oyunları, ip cambazlığı, boks gibi sportif gösterilerin olduğu şenliklerde, tiyatro oyunları da oynanmaya başlanmış fakat eğlendirici, oyalayıcı yan hep ağar basmıştır. Mehmet Fuat "Tiyatro Tarihi" adlı kitabında bir oyun gösterimini şu şekilde anlatmaktadır:

"Çok kalabalı bir stadyum, sahnede iki kişi maskelerle ölümüne mücadele etmektedir. Bu bir gladyatör dövüşü değil, mücadele edenler de gladyatör değil, Romall oyunculardır, çok kisa süre sonra bir oyuncu ölecektir. Gladyatör dövüşünde gerçekleşen ölüm gibi, bu oyunda da ölüm gerçek olmalıdır. Çünkü seyircinin beklentisi bu yöndedir. Burada amaç kodlarında savaş olan bu insanlara, acımasızlığl sürekli hatırlatmak ve yaşam biçimi olan bu şiddeti diri tutmaktır. Bu da köleler ve haklar olmayan insanlar üzerinde yapılmalıdır. Öyle vahşi bir durum söz konusudur ki, eğer bir oyuncu, bu ölüm oyunundan kaçarsa, yakalandığı zaman öldürülmekle kalmiyor önce işkence ediliyordu.” (Fuat, 2010, s.49). 
Roma'da anlaşılacağı üzere komedi oyunları revaçtaydı. Bu durum devletin ve toplumun tiyatroya bakışının bir tezahürü olarak okunabilir. Oyunculuk eğlencelik bir icra için yapılmalıdır. "Şairin amacı eğlendirmek ve yarar sağlamaktadır." (Carlson, 2007, s.26). Bu minvalde sirk oyunları, Atellan farsları oynanmaktaydı. Daha sonra pantomim oyunları yaygınlaşmıştır. En fazla tutulan oyunlar bedene dayalı bu gösteriler olmuştur. Bu oyunlar ve oyuncular, zamanın düşünürlerinden ve daha sonra da Kilise'den olumsuz tepki görmüştür. Oyunculara çok ağır suçlamalar itham edilmiş, söylenebilecek tüm kötü sıfatlar dillendirilmiştir. (Pignarre, 1991, s.31).

Oyuncuları ifade etmek için Roma'da genelde histriones terimi kullanılmasına karşın cantores (söylevciler) teriminin de kullanıldığı görülmektedir. Düşük bir meslek olan oyunculuk için, icra edilen oyun türüne göre de bir mertebe vardı. Örneğin kurallı dram oyuncusu, mim gösterimcisine göre daha itibarlı konumdaydı. Mimus ya da saltator denilen mim oyuncusu ise daha düşük bir seviyededir. Roma Devleti'nin son dönemlerinde bütün oyuncular için histriones teriminin kullanılmaya başlanmıştır. Oyuncular genelde erkeklerden oluşmaktaydı. Sadece mim oyunlarında kadınlar sahneye çıkmaktaydı. Oyuncuların toplumsal itibar noktasında diplerde olmasına karşın çok az da olsa, bu meslekle itibar ve maddiyet kazanan oyuncuların varlığı da söz konusudur. Romalı ünlü bir oyuncu olan Roscius ve çağdaşı Aesopus bu duruma örnek teşkil etmektedir. Roscius köle değildir ve sonradan soyluluğa yükselmiştir. Aesopus zengin olması ve yeteneği sayesinde, Optimate denilen kamu işlerinin denetiminde etkin olan bir topluluğunun üyesiydi. Aynı zamanda iki oyuncu da yazar ve oyuncular derneği olan collegium poetarum'un üyeleri arasındaydılar (Brockett, 2000, s.77). Fakat alımlayıcı için tipik davranış modu değişmediği için oyuncu ne kadar popüler olursa olsun, seyirci oyuna her türlü müdahale edebiliyordu. Andronicus'tan "Bir seferinde seyirci defalarca bazı favori satırların tekrarlanmasını talep etmiş, Andronicus'un sesi başarısız olmuştur." (Kenneth \& Henry, 1919).

İ.Ö I. yüzyıl itibarıyla gösterim anlamında yıldız oyuncu önemli konuma geçmiş, kurallı dram ve oyuncusu gerilemiştir. Bu dönemde aktörlerin yeteneklerini sergilediği sahnelerin revaçta olduğu görülmektedir. Özellikle gösterilerde bir oyuncu öne çıkmaya başlamış ve öne çıkan oyuncular yıldızlaşmıştır. Mim oyuncularının en hünerli olanları ciddi hayran kitlelerine ulaşmıştır. Hatta İ.Ö 6. yüzyılda mim oyuncusu olan Theodora, Doğu Roma İmparatoru Justinianus ile evlenmiştir. (Tereman, 2007, s.113). Roma'nın son zamanlarında ise durum yine başa sarmıştır. Dönemin en popüler oyuncuları; ip cambazları, hokkabazlar, kılıç yutan, ateş yiyenler gibi daha çok hünere dayalı performans yapan kişilerdir. Gelinen bu noktada oyunculuk daha fazla olumsuz tepkiler almaya başlamış, gezici mimus ve pandomim oyuncularının açık saçık sahneleri bu olumsuz durumun daha da palazlanmasına sebebiyet vermiştir.

\section{Ortaçağ'da Oyunculuk}

Oyunculuk mesleği için Ortaçağ (476-1450) sessizlik çağı olarak okunabilir. Roma döneminde gereken değeri göremeyen aktörler, bu dönemde daha da zor durumda kalmış, köşe sıkıştırılmış, olmadık suçlamalara maruz bırakılmış hatta öldürülmüştür. Doyumsuzluk politikası neticesinde Roma İmparatorluğu'nun topraklarını genişletmesi, merkezi otoritesinin zayıflamasına sebep olmuştur. Ve nihayetinde M.S 476 yılında Roma, Batı ve Doğu diye ikiye ayrılmıştır. Bu tarih Ortaçă̆'ında başlangıcı olmuştur. Yani Ortaçağ, Roma'nın kalıntıları üzerine doğmuştur denebilir. (Le Goff, 1992, s.3).

Oyunculuk sanatının mecrası olan tiyatro için pagan inancı, Roma'da da devam etmiş, tiyatral anlamda Yunan'ın kötü kopyası da olsa varlığını sürdürmüştür. Sessizlik çağıyla beraber 4. yüzyıl itibarıyla dini açıdan yaşanan gelişmeler, tiyatronun kaynağı pagan inancını ve onun sanatsal tezahürü olan oyunculuk mesleğini olumsuz olarak etkilemiştir. Fakat paradoks bir şekilde pagan kaynaklar bir yolu bulunarak kullanılmaya devam etmiştir. "Pratikte, ortaçağın din adamları, çok fazla çaba harcamadan vicdanlarını mutlu tutarken 'pagan' kitapları 
kullanmanın birçok yolunu bulacaklardı. Cluny'deki kütüphanede, eski bir yazarın el yazmasına bakan bir keşiş, kulağını pençesiyle kaşıyan köpek gibi kaşımak zorunda kalmıştır. Çünkü pagan, Ortaçă̆'da bu hayvanla eşdeğer de tutulmaktadır." (Le Goff, 1991, s.114). Fakat gittikçe yayılan tek tanrılı inanç sistemi, topraklarını genişleten Roma İmparatorluğu'nca tamamen kabul edilip yaygınlaşmaya başlamış "bu dinin ilk mezhebi Gnostisizm ögretisini yayma çabalarl, Hıristiyanlar ve Paganlar arasında çatışmaları körüklemiştir. Gizemli inanç arayışları, doğu mistisizme ilgi ve Museviliğin katkası bu dinin (Hıristiyanlı) yayılmasını hızlandırmıştır." (Doğan, 2003, 73). Zamanla da "Hıristiyanlık'ın baş temsilcisi Katolik Kilisesi'nin etkisiyle Antik tiyatro çöküntüye uğramış, (bu çöküntü) Rönesans tiyatrosunun yeşermesine dek sürmüş, feodal toplum düzeninin karşıllğı bir oyunculuk ve tiyatro sanatı oluşmuştur." (Çalışlar, 1995, s.472).

Kilise'nin birçok alanda etkin olması ve zamanla önemli bir güç haline gelmesi, doğal olarak pagan inancına dayalı oyunculuk sanatını da olumsuz manada etkilemiştir. Bahsedildiği üzere Roma döneminde oyuncunun, şehveti, cinselliği ve eğlenceyi çağrıştıran performansları, sessizlik çağında Kilise'nin mücadele verdiği odak noktadır. Çünkü seyirci bu oyunlarla akıl dışılığa, pornografiye, şiddete yönelmekte ve geçici dünya hayatında olumsuz dürtülere kapılarak bedenini şehvete kurban etmektedir. O nedenle, Ortaçağ'da tiyatro gösterimlerine ve oyunculara çok katı yasaklar getirilmiştir. Fakat halkın tiyatro izleme isteğini yasaklar engelleyememiştir. Bu durum karşında din adamları, topluma tiyatronun ve onun icracılarının kötülüklerini anlatmışlar ve bir dizi suçlamalarla gözden düşürmeye çalışmışlardır. Çünkü "kiliseye göre günahkâr doğan insanın günahlarından arınması için öncelikle bir kul olduğunun bilincinde olması ve kilisenin buyruklarına boyun eğmesi gerekmektedir. Ve bedenin tüm isteklerini reddederek kurtuluşa erebilir." (Şener, 2003, s.70). Fakat oyuncuların icra ettiği bu meslek, aktörün vücudunu sergilemesi neticesinde maddi ve fiziksel gerçekliğinin o anda gösterilmesi, seyircide irrasyonel ve şiddet dürtülerini açığa çıkarmaktadır. (Vicentini, 2012, s.4). Yani Kilise'ye göre dünyevi olan oyunculuk sanat, insanlığın yoldan çıkmasına sebebiyet vermektedir. Çünkü aşırılıklarla haddi aşan bu meslek erbabı, günah işlemekte ve günaha sevk etmektedir. Artık oyuncular, kilise babalarının şiddetli bir şekilde kınadıkları hedef haline gelmiş ve haklarında en aşağı tanımlamalar yapılarak gözden düşürülmeye çalışılmıştır. "Hıristiyan ögretisinin yayılması için çaba gösteren bazı yazarlar ve kilise babaları tiyatroyu 'Venüs'ün tapınă̆g', tüm günahların siğınă̆l, utanmazlığın temeli ve Tertullian'ın etkili bir ifadesi olarak 'Şeytanın Kilisesi' olarak tanımlamışlardır." (Schyberg\& Carlson, 1961, s.70). Çünkü tiyatro, en önemli bileşeni oyuncu marifetiyle Moliere'nin meşhur sözü olan "bu sanatın yegâne hedefi seyircinin hoşuna gitmektir" (Gerçek, 1944, s.13) mottosuyla her türlü ahlaksızlığın kaynağıdır. Kilise ahlaksızlığa kapılmama noktasında halkı sürekli uyarmakta ve bir gün asıl oyunun, üzücü oyunun geleceğini, işte o günün de, buna sebebiyet veren oyuncuların bir trajedide yaptıklarından daha yüksek sesle çı̆̆lık atacakları kıyamet günü olduğunu her platformda söylemektedirler. (Schyberg\& Carlson, 1961, s.70).

Sessizlik çağında kilise, dünyevi olan bu mesleği ve icracısı oyuncuyu, yoldan çıkaran, insanı insan olmanın kodlarından ayıran yegâne sebep olarak görmekteydi. Bu meslek erbabı sahnede gülüyor, başka insanların yerine geçiyor, hayatı ve bir bakıma kendisine biçilen kaderi sorguluyordu. Tüm bunları yaparken Tanrı'yı ve onun dinini hiçe sayıyordu. Fani olan insan aşırılık içindeydi. Oyuncular, eleştirel bir şekilde yaşamı ele alarak zihinlere şüphe düşürüyorlardı. O nedenle de çok tehlikeliydiler. $\mathrm{Bu}$ görüşe karşıt olarak, oyunculuk mesleğini iyi göstermek ve dine aykırı olmadığını ispatlamak için bir takım girişimler de oluyordu. Bunlardan biri Choricius'un "Aktörlere Övgü" adlı eseridir. Bu eserde gülmenin günah olmadığı, aksine hayvanla insanı ayıran en önemli özellik olduğu, oyuncunun canlandırdığı kişinin sadece bir rol olduğu, asla o kişinin gerçek bir karakteri yansıtmadığı anlatılmaktadır. Tiyatronun amacının yaşamı resmetmek, olanı göstermek olduğu için hayata bu denli benzediği vurgulanmaktadır. Ayrıca Choricius bir öz eleştiri yaparak bazı mim oyuncularının açık sahneler oynadığını, bu haliyle zina yaptığını, fakat bu durumun geneli yansıtmadığını, suçun 
bütün oyuncularda değil, açık sahneler icra edenler de olduğunu ifade etmektedir. (aktaran Nutku 1995, s.45).

$\mathrm{Bu}$ çağda oyuncuların hem tanımı hem değer olarak konumu en aşağı şekilde ifade edilerek, yaptıkları işin ne denli kötü ve çirkin olduğu anlatılmak istenmektedir. Oyuncular utanmaz kadını andıran kıyafetler giyen ve onların taklitlini yapan canlandırıcılardır. Oyuncular, kâfirler ve yahudiler gibi kötü şöhretli dışlanmış kişilerdir. O nedenle oyuncuları memnun etmek doğru değildir. Onları hoşnut etmek Tanrı'ya karşı gelmek, kötülüğü pekiştirmek anlamına gelmektedir. Alcuin üçüncü mektubunda İtalya'ya giden öğrencilerine oyuncuları memnun etmek yerine fakirlere bakmanın Tanrı'nın nazarında çok değerli olduğunu yazmıştır. (Ogilvy, 1963, s.605, 608, 609). Bu bakış açısı Avrupa'da kilise hizmetinde olanlara bir emir gibi telkin edilerek oyuncular ve meslekleri itibarsızlaştırılmaya çalışlıyordu. Bu minvalde Psikopos Quivel "Statutes of Exeter" adlı eserinde din adamlarına uyarılarda bulunmakta onların nasıl bir yaşam şekli benimsemeleri gerektiğini anlatmaktadır. Bu eserde Quivel din adamlarının hayatlarının ölçülü, mütevazı olması gerektiğini vurgulamaktadır. Rahiplere, oyunculukla ve diğer eğlence alanlarıyla uğraşan (histrionibus \& ioculatoribus) kişilerle ilişki kurmamaları noktasında uyarılarda bulunmaktadır. Ve rahipler bu tür insanları evlerine davet etmemelidir, hiçbir din adamı bu insanların gösterilerini izleyen seyirciler arasında yer almamalıdır. Bu yaklaşımın tezahürü olarak Londra'da 1542 ve 1545 tarihli belediye meclisi kararında oyunculuk mesleğinin palazlanmasını engellenmek için lonca salonlarının kullanılmasına yasak getirilmiştir. (Wasson, 1984, s.2, 5).

Oyunculuğun Kilise'nin hedefinde yer almasının temel sebebinin, pagan inancina dayalı meslek kolu olmasından kaynaklandığı kuşkusuzudur. Pagan inancıyla "Yunan mitolojisinin önemli bir başarısı ve işlevi dinsel ihtiyaçların ve amaçların karşılanabilmesi için öykücülügün gelişmesine olanak tanınmasıdır." (Freeman, 2003, s.225). Anlatılan mitler tiyatronun köken kuramını oluşturmaktadır. $\mathrm{Bu}$ öyküler çok tanrılı bir kültürün neticesinde ortaya çıkmıştır. Tek tanrılı bir inanç sistemi olan Hıristiyanlık, doğal olarak çok tanrılı inanç sisteminin tezahürü olan tüm yaşam biçimini reddedecektir. Öykülerde olduğu gibi, olmayan bir olayı ve kişiyi tüm bedeniyle ifa eden oyuncu aslında yalan söylemektedir. Bunu da müstehcen ifade biçimiyle haddini aşarak yapmaktadır. Zaten pagan kültüründe, özellikle de kırsal mitlerde tanrılar arasında yalan dolan ve aldatmaca yaygın bir şekilde maharetmiş gibi işlenmektedir. Zeus'un oğlu aynı zamanda da özel ulağı Hermes'le olan tüm iletişimi yalan üzerine kuruludur. Aynı yalan oyunu Troya savaşında da tanrılar arasında olmuştur. Olimpos'un baş Tanrısı Zeus'un kızı Sparta kralı Menelaos'un eşi güzel Helana'nın, Troya prensi Paris'le kaçması sonucu yapılan kuşatmada, tanrıların ve tanrıçaların bir bölümü Troya tarafinda olurken, diğer bir bölümü de Mikenliler tarafinda yer almıştır. Yani yalan dolanlar, tarafgirlik tanrıların eğlencesi durumundadır. $\mathrm{Bu}$ durum birçok tiyatro oyununun konusunu teşkil etmiştir. Örneğin Platus'un bir eseri olan Roma dönemi dışında 17. ve 18. yüzyılda Molière ve Heinrich von Kleist tarafından da kaleme alınan "Amphitryon" oyunu "Zeus'un türlü oyunlar yaparak, kllık değiştirerek, oğlunu da oyunlarına alet ederek beğendiği kadını elde etme çabasını konu etmektedir." (Sivri \& Ciner, 2010, s.132).

Yalan dolan ve dolantılara dayalı pagan inancının tezahürü olan tiyatro/oyunculuk, belli bir bedensel estetik de içermektedir. Fakat Ortaçağ'da estetik, bedenin kilise görevlilerinin kıyafetleri içinde gizlenmesi ve bu sayede dünyevi hazdan uzaklaşılmasıdır. Tanrısal ve güzel olan öteki dünyadadır. O nedenle bedenin teşhirine dayalı bu sanat, Kilise için çok ciddi bir problematiktir. (Ziss, 1984, s.180). Sonuçta, yalan, dolan, aldatmacayla gerçek çarpitılmakta ve insanlar etki altına alınmaktadır. "Çünkü tiyatro, (en önemli bileşeni olan oyuncu vasitasıyla) ontolojisi gereği bir mimesistir. Kurgulama ya da kurmaca eylemdir. Gerçeğin '-mış gibi' yapılarak taklit edilmesi ve seyircinin bu kurmacayla kandırılması değil, bilinçli bir şekilde bu yalana ortak olmasıdır." (Öztürk Çetindoğan, 2015, s.121).

Yani oyuncular eliyle bir eğlence icra edilerek, tanrısala yaklaşan bir sanat değil aksine dinsel kapsam dışında kalan bir gösteri sergilenmektedir. Kilisenin amacı ise ruhsal olanı büyütüp yüceltmek, insani ve tensel olanı da göz ardı etmektir. Saint Augustine sanatı tanrısal bir eylem 
olarak nitelemesine rağmen bu sahne gösterisine kuşkuyla bakmaktadır. Yani o da Platon gibi düşünmektedir. Trajik oyunlarla insan ruhu tuzağa düşürülüp yozlaştırılmaktadır. Heyecandan insanın kurtulması gerekirken, oyuncular eliyle bu olumsuz yön harlanmaktadır. Özetle; Kilisenin oyunculuk sanatına düşmanca tavrının nedenleri şu şekilde açıklanabilir: Oyunculuk ve tiyatro yalandır, gerçek olmayanı söylemektedir; insana zarar veren hisleri uyarmaktadır; dine aykırı düşen bir durumun oluşmasını sağlamaktadır; ahlak dışıdır, inançsızlığı teşvik etmektedir. Kişiyi yoldan çıkararak boşluğa düşmesine sebebiyet vermektedir. (Şener, 2003, $70,71)$.

Kilise'nin gücü ve otoritesi arttıkça nüfuz ettiği alanlarda daha etkili olmaya başlamıştır. Genel görüşe göre en etkin olduğu zaman dilimi X. yüzyıl ile XIII. yüzyıl arasındadır. Öğretisini daha fazla insana yaymak için tüm yasaklara rağmen engelleyemediği tiyatrodan faydalanmıştır. Amaç da cahil olan halkı tiyatro oyunlarıyla etkileyerek Hıristiyan öğretisinin yayılmasını hızlandırmaktır. Kilisede Ortaçağ'ın başından beri yapılan bazı törenler, tiyatral yapıyı andıran merasimler şeklinde olduğu için, Kilise'nin bu sanata el atması aslında uzak olmadığı bir alana girişi olarak yorumlanabilir. 'Mass ve Saatler' ayini bu duruma bir örnek teşkil etmektedir. İki bölümden oluşan Mass ayini giriş, ekmek ve şarapla kutsanma şeklinde yapılmaktaydı. Giriş bölümünde İncil'den dualar okunarak günün koşullarına göre dua seçimi yapılırdı. Sonra kalıplaşmış kutsanma ayinine geçilirdi. Mass zorunlu bir ayin değildi konusu günden güne değişirdi. O nedenle tiyatroya daha uygun bir yapı arz etmektedir. Sonuçta "Mass ve Saatler ayinin tiyatronun ortaya çıkmasında rolü büyüktür" (Brockett, 2000, s.100). İronik bir şekilde belli belirsiz yapılan bu teatral performanslara Kilise izin veriyordu. Kutsal metinlerden alınan öyküler rahipler tarafından Latince diyaloglar şeklinde söyleniyordu. $\mathrm{Bu}$ "diyaloglardan rahiplerin geliştirdiği basit dramatik yapılar zaman içinde karmaşık liturjik dramalar haline gelmiştir." (Carter, 2011, s.19). Zamanla bu yap1 daha da geliştirilerek konusunu İncil'den, Hıristiyan öğretisinden alan oyunlara dönüşmüştür. "Oyunların konuları hep İncil'den ve İsa ile azizlerin yaşamlarından alınıyordu." (Baltacıoğlu, 2006, s.16). Başlangıçta oyuncular da din görevlilerinden oluşmaktaydı. Oyunculuk alanında eğitimi olmayan bu kişiler, rolü nasıl oynayacaklarını bilmedikleri için ve bu işi bir ibadet olarak düşündüklerinden dolayı, oyunculuk sanatının kurmaca gerçeğine aykırı çok tehlikeli bir icra yoluna sapmışlardır. Yani bir rolü gerçekten yapmak. Öyle bir durum oluşmuştur ki kutsal kişileri oynayan din görevlisi oyuncular, daha sevap olur diye canlandırdıkları kişilerin başına gelenleri gerçekten yaşamışlar, bu nedenle birçok oyuncu icra sırasında bayılmış, yaralanmış hatta ölümden dönmüştür. Din görevlisi oyuncular için seyirciyi etkilemenin tek yolu da gerçeğini yaşamaktır. Kilise'nin hegemonyasına giren tiyatro ve icra yöntemi oyunculuk tuhaf bir hal almıştır. Bu oyunlarda rol alan oyuncuların ücretleri bile rolün kutsiyetine göre ödenmeye başlanmıştır. "Tanrıyı oynayan kişiye, kisalık ve uzunluk gözetilmeksizin en yüksek ücret, rahibi oynayana bir düşük ücret, şeytanı oynayana ise rolü uzun olsa bile en düşük ücreti ödeniyordu." (Nutku, 1995, s.44).

Kiliselerde oynanan oyunlar yavaş yavaş kilise dışına taşmaya başlamış ve temsiller Latince yerine halk diliyle icra edilir olmuştur. Halk kendi dilinde sahnelenen oyunlarla, kültür olarak var olan ludus (oyun) ve dramatik sezgi yönünü yeniden keşfetmeye başlamıştır. İlginin artması ve kalabalık seyirci kitlesi nedeniyle, din görevlileri dişında oyunculara da gereksinim duyulmaya başlanmıştır. Ayrıca rahiplerin oynayacakları roller için çok fazla hazırlık yapması gerekiyordu, bu da onların kilisedeki rahiplik görevlerinin aksamasına sebep oluyordu. (Brockett, 2000, s.135). Kilise de amatör oyunculardan destek almak suretiyle kendince bir çözüm üremiştir. Sevap kazanılacağı düşüncesiyle esnaf loncaları da destek vermeye başlamıştır. Fakat zamanla, oyunların masraflarını üstlenen esnaf loncaları, çok ayrı bir uğraş olan bu mesleği kiliseden uzaklaştırmışlardır. Kilise sadece denetleme mekanizması olarak konumlanmıştır. Durumun bu şekilde gelişmesi ve oyunlarda kilise dişında halktan amatörlerin olması, icra noktasında bazı güldürü öğelerinin de yer bulmasına zemin hazırlamıştır. "Fransa'daki örneklerinde olduğu gibi, dinsel oyunların sonlarında Farslar oynanmaya başlanmış, bu durum dinsel tiyatronun dünyevi ve beşeri görünüme bürünmesinin yolunu 
açmıştır." (Çalışlar, 1995, s.447). Zamanla oyunlar Kilise'nin denetimden çıkmaya başlamış, Kilise de rahiplerini bu gösterilerden çekmiştir. İlk önce onların yerine amatörler sonra da profesyonel oyuncular istihdam edilmeye başlanmıştır. Bu gelişmelere ek olarak kiliseler arasındaki papalık mücadelesi, eğitimdeki gelişmeler, matbaanın icadı, antik eserlerin çevirilerinin yapılması, coğrafi kesiflerin sağladığı bilgiler din öğretisinin zayıflamasına ve laik bir sanatın filizlenmesine olanak sağlamıştır. Fakat Kilise'nin oyuncular noktasında tutumu özgül ağırlığını hep korumuştur. $\mathrm{Bu}$ duruma paralel olarak oyunculuk mesleğinin ve icracılarının günah işlemediği, topluma iyilik katmaya çalıştığı söylemleri de yaygınlaşmaya başlamıştır. Özdemir Nutku (1995) Aquino'lu Thomos'tan durumu şu şekilde aktarmaktadır: "Bir histrio'nun (oyuncunun) mesleği, esasında hiç te yasa dışı bir şey değildir. Bu meslek belli bir ölçü içinde, insanlığın dinlenmesi içindir ve mesleğini uygun bir zamanda, uygun bir biçimde yapan histrio da asla bir günahkâr değildir." (s. 44)

\section{Rönesans'ta Oyunculuk}

Bedenin, baştan çıkarıcı ve kışkırtıcı kullanıldığı için günah sayıldığı bir dönem olan Ortaçağ'da, zamanla Kilise'nin baskılarının azalması, insan odaklı gelişmelerin palazlanması ibrenin antik dünyaya çevrilmesine ve yeniden yorumlanmasına sebep olmuş ve oyunculuk mesleğinin Rönesans'la itibar kazanmasını sağlamıştır. Dolayısıyla bu dönem için tiyatro, Antik Yunan ve Latin izleriyle örülmüş bir yapı arz etmektedir. Yani Ortaçağ'ın uzun parantezi sona ermiş antik geleneklere dönüş başlamıştır. Bir çok kuramcıya göre antikite Rönesans’1 yarattı̆̆ kadar, Rönesans da antikiteyi yaratmıştır. O nedenle metamorfoz anlayışıyla eser üreten iki klasik yazar Oviud ve Apuleius'un bu dönemde çok ilgi görmesi tesadüfi bir gelişme değildir. Bu durumu daha iyi alımlayabilmek için brikolaj önemli metafor olarak görülebilir. Yani bir yapının parçalarından başka bir yapı oluşturmak. Durum böyle olunca aslında gelişmeler hem döneme ait hem de ait olmayan bir bütünlük göstermektedir. "Dönemin yazarlarından Hollandalı hümanist Justus Lipsius "Politics" adlı eserinde "her şey benimdir." fakat ayn zamanda "Hiçbir şey bana ait değildir." Fikrini savunmaktadır. Rubert Burton da "Anatomy of Melancholy" eserinde "hepsi benim, hiç biri benim değil" (Omme meum, nihil meum) vurgusu yaparak Rönesans dönemini yansıtmışlardır." (Burke, 2015, s.29, $30)$.

Yeniden doğuş anlamına gelen Rönesans'ta antikiteden ilhamla, yazar ve eleştirmenler bu kadim sanatı, Kilise'nin olumsuz tutumuna karşs savunmak durumunda kalmışlar ve oyunların eğitici olduğunu, oyuncularının da bu önemli işleve katkı sağladığını dile getirmişlerdir. Her ne kadar Kilise'ye karşı oyunculuk mesleği ve icracıları savunuluyor olsa da, Ortaçağ'ın karanlık döneminde paradoks bir şekilde, bu mesleğin ayakta kalması ve varlığını sürdürmesi yine Kilise sayesinde olmuştur. Bahsedildiği üzere Hıristiyan öğretisinin kilise babaları tarafindan cahil halka oyuncu marifetiyle öğretilme düşüncesi, oyunculuğun/tiyatronun hayatta kalmasını sağlamıştır. Halk tarafından benimsenen tiyatro, yasakların gücünü kaybetmesiyle XV. ve XVI. yüzyılda Avrupa'da hareketlenmeye başlamış, toplumun tüm kesiminin ilgi odağ 1 haline gelmiştir. Tiyatronun bu şekilde bir karşılığının olması toplumun tüm kesimlerine hitap eder duruma gelmesi, oyuncuların ve bu mesleğin müspet istikamette kabulünü sağlamıştır. Oyunculuk sanatı önem kazanmış, sahneler daha estetik bir şekilde icra edilmeye başlanmıştır. Ortaçağ'da basit görülen ve eğitimsiz insanların kalabalıklığı son bulmuştur. "Ortaçağ da görülen rolü olsun olmasın ilgiyi dağıtan oyuncular sahneden çekilmiş, oyunculuk gösterişli ve etkili bir konuma yükselmiştir."(Şener, 2003, s.74). Bu gelişmeler Avrupa'nın farklı ülkelerinde, kendi kültürlerine, toplum yapısına, teknolojik gelişmelerine bağlı olarak ulusal sanat yapısını da belirlemiştir.

XV. ve XVI. yüzyıllarda Rönesans düşüncesinin toplumda, hem yaşayış hem de sanatsal anlamda değişiklik getirmesine rağmen, dinsel dramanın tüm Avrupa'da amatör oyuncularca sergilendiği görülmektedir. Örneğin Floransa'da 'Ermiş Yohanna Günü Şenliği' kapsamında Tevrat ve İncil'den bazı bölümler sahnelenmiştir. Yine "Viyana Paskalya Oyunu" her yıl düzenlenmeye devam etmiştir. Metz'de "Ermiş Katerin" oyunu 18 yaşında genç bir kız 
tarafından oynanmıştır. Fakat amatör oyuncular dinsel konuların içine güldürü öğeleri katarak icrada bulunuyorlardı. O nedenle de Paris Belediyesi 1548 yılında dinsel oyunların içine dünyevi sahneler konulduğu gerekçesiyle, bu oyunları yasaklamıştır. Kentin dış mahallelerinde ve banliyölerde icra edilmesine izin verilmiştir. Yani oyuncular da seyirciler de halk güldürüsü ve töreci oyun (moralite) arasında kalmıştır. (Nutku, 1995, s.57). Bu durum Kilise'nin baskısının hala devam ettiğini göstermesi bakımından önemlidir. Bazı devletlerin de dini bir yaklaşım sergilediği ve Kilise'nin öğretilerinin etkisi altında olduğu görülmektedir. Ortaçağ'da Kilise'nin, oyunculara ve tiyatroya karşı ayartıcı, kaba, ruhu aşırılıkla bozan bir sanat olduğuyla ilgili suçlamaları 17. yüzyıla kadar sürmüştür. İspanya, İngiltere gibi birçok Avrupa ülkesi, bu olumsuz tutumun yanında yer almıştır. Devlet yöneticileri dinsel oyunların kötüye kullanıldığı, oyuncuların disiplinsizliği ve seyircinin de bu duruma paralel olarak taşkınlığı nedeniyle ve yasaların ihlal edildiği gerekçesiyle bu oyunları Kilise'nin görüşleri doğrultusunda yasaklamıştır. Kilise durumu öyle ileri götürmüştür ki bazı felaketlerin sorumlusu olarak oyuncuları ve tiyatroyu göstermiştir. 1577 yılında T. Wilcocke adında bir rahibin verdiği vaaz bu duruma örnek gösterilebilir. Rahip T. Wilcocke verdiği vaazda veba salgınından dolayı Londra'da tiyatroların kapatılmasının hastalık için sadece geçici bir çözüm olduğundan bahsederek, asıl sorunun ve sorumlunun oyuncular olduğunu, oyuncular yüzünden insanların günaha battığını ileri sürmüştür. Bu tür vaazlar nedeniyle de devletler hatta bazı yazarlar da Kilise'nin yanında yer almışlardır. Devletler, ahlaka aykırılığından dolayı düzenin bozulduğunu ileri sürerek denetim ve yasaklama yoluna gitmişlerdir. Bazı yazarlar da pagan kökenli tiyatro için "şeytan yuvası" tabirini kullanmışlardır. Hatta Gosson adlı bir yazar "School of Abuse" başlıklı yazılar kaleme alarak oyuncuları ve tiyatroyu 'Sövgü Okulu' olarak değerlendirmiştir. Bazı yazarlar da din öğretisine aykırılık dışında farklı eleştirilerde de bulunmuşlardır. Örneğin Cervantes, kendisi de halkın sevdiği fantastik ve gerçeğe aykırı karakterlere oyunlarında yer verdiği halde, bu tarz tiyatro gösterimlerine karşı olmuştur. Bunun neticesi olarak bu tarz oyunları yazan ve icra eden oyuncuların rezalete sebebiyet verdiklerini dile getirerek Saray'ın, oyunları ve oyuncuları denetlemesi gerektiğini savunmuştur. (Şener, 2006, s.77,78).

Tüm bu suçlamalara karşı aydın yazarlar bu kadim sanatı bütüncül bir şekilde savunmuşlardır. $\mathrm{Bu}$ savunma hem suçlamalara bir cevap hem de bu çağın tiyatro sanatına ölçüler getiriyordu. XV. ve XVI. yüzyıl başı klasik yapıtlar bulunmuş, incelenmiş, ortaçağ düşüncesi çürütülmüştür. Eflatun, Aristoteles gibi yazarların eserleri ortaçağ mistisizminin yıkılmasına ve hümanizmanın güçlenmesine önemli katkılar sunmuştur. Geçmişteki gibi insan merkeze alınarak, güzellikleri ortaya çıkarılmıştır. Hümanizmanın getirdiği rüzgârla 'Bilgi' canlanmış, bu da sanatların gelişimine çok önemli katkılar sağlamıştır. Bahsedildiği gibi antikiteye yöneliş, Rönesans döneminin tiyatro sanatı için en belirgin özelliği haline gelmiştir (Coşkun, 2003, s.57). O nedenle "tarihçiler Rönesansı, antik çă̆ üstüne yapılan incelemelerin yenilenmesi olarak tanımlarlar."(Hançerlioğlu, 1967, s.232).

Rönesans döneminde tiyatro/oyunculuk temelde savunulma yoluyla hayat bulmuştur. $\mathrm{Bu}$ amacın altında yatan temel paradigma insan merkezli yaşam biçimine geçilme isteğidir. 15. ve 16. yüzyılda Avrupa'da yaşayan insanlar, ortaçağın gelenek ve din yapısıyla örülü bir yaşam biçimi içinde kendilerini geliştiremeyeceklerini, daha iyi bir yaşam kuramayacaklarını anlamışlardır. Bu durumu değiştirmek ve yeni değerler oluşturabilmek için çabalamışlardır. Bu çabaların merkezine de insanı koymuşlardır. Bu sayede de hümanizm düşüncesi palazlanmıştır. Böylece ortaçağın dinsel öğretileriyle algılanan evren, toplum ve insan anlayışı, insan merkezinde bireyci yaklaşımla ele alınmıştır. Sonuçta "Tanrı Devleti yerine tekrar yeryüzü devleti; dinsel bir kozmoloji yerine fiziksel bir kozmoloji; insanın kul olarak görüldüğü bir toplum/devlet düzeni ileri sürülmeye başlanmıştır." (Çüçen, 2006, s.26).

Bahsedildiği üzere Rönesans döneminde tiyatro için bir yenilik getirilmemiş Antik Yunan ve Roma'nın tiyatro anlayışı yinelenmiştir. İlk önce Roma'dan Horatius'un "Ars Poetika"sından, sonra da Yunan'dan Arsitoteles'in "Poetika"sından etkilenilmiştir. Aynı zamanda Platon'un da sanatçı için esin kaynağı görüşünün de bu dönem için etkileri söz konusudur. Antik dönemin 
yeniden canlanmasıyla tiyatro eserleri ardı ardına çıkarılarak, oyunculuk sanatından çok kuramsal yönün gelişimi söz konusu olmuştur. Oyunculuk sanatı metnin gerisinde kalmıştır. Bu gelişmelere ek olarak sahne makinelerinin gelişimi, oyun metinlerinin de, oyunculuğun da önüne geçmiştir. Tiyatronun kuramsal platformda sıkışması ve teknolojik gelişmeler, profesyonel oyuncuların kendi yolunu çizmesi zorunluluğunu doğurmuştur. Profesyonellere sadece bazı metinlerin canlandırılması için ihtiyaç duyulduğundan, onlar da gezici topluluklar halinde mesleklerini icra ediyorlardı. Bir şekilde amatör oyuncularla rekabet etmek zorundaydılar. Kilise'nin ve devletin yasakları ve vergi yükü nedeniyle kıt kanaat geçiniyorlardı. Saraylarda oyunculuk yapan amatörler ise iyi koşullarda mesleklerini icra ediyorlard1. Fakat zamanla, rol ezberleme gibi zorluklar nedeniyle amatörlerde bıkkınlık görülmeye başlanmıştır. Bıkkınlığın bir başka sebebi de profesyonel oyuncuların kendilerinden daha iyi performans sergilemesi gerçeğidir. Saray da bu durumun farkına varmış ve ucuz olan profesyonel oyuncuları tercih eder olmuştur. Prensler saraylara artık profesyonel oyuncular çağırmaya başlamıştır. Bu durum oyunculuk mesleğinin değerini arttırmış ve nitelikli oyuncuların rağbet görmesini sağlamıştır.

\section{SONUÇ}

Bir sanat dalının köklü geçmişe sahip olması, onun çok bilinen ve değer gören bir sanat olduğu anlamına gelmemektedir. Dönemin şartları bu mesleği konumlandırmakta ve olumlu-olumsuz gündemine almaktadır. Antik Yunan dönemimin hem düşünsel hem de yaşamsal noktada sanatı görme biçimi, oyunculuk sanatının, sanatsal ve toplumsal önemini göstermesi bakımından önemli bir örnektir. Yunan'da tiyatronun böylesi değer görmesi ve gelişimi toplumla kurduğu bağ ile ilintilidir. Öyle ki oyuncuların ve tiyatrocuların devlet tarafindan önemli görevlere getirilmesi, sahnelerin ibadethanelerin yanına yapılması, tiyatro festivallerinin düzelenmesi, devletin bu festivalleri finanse etmesi, tiyatro ve oyunculuk sanatını görme biçiminden kaynaklanmaktadır. O nedenle oyunculuk sanatının kaynağı yaşam olmalıdır. O nedenle tiyatro bir toplum bilimidir. Gelişmesi, yaygınlaşması ve sanatsal estetik kazanması yaşamla kurduğu bağ ile sağlanabilir.

Tiyatro ve oyunculuk sanatı yaşamın yankılanmasıdır. Tiyatronun estetikten yoksun bir hal alması, tiyatro/oyunculuk alanda eğitimin önemsenmemesi, bu sanatın gelişiminin sekteye uğraması ve itibarının yerle bir olması dönemin yapısının bir çıktısı olarak okunmalıdır. Roma döneminde tiyatroya aşağılık bir meslek olarak bakılması, Romalıların yaşamı görme biçimiyle alakalıdır. Yani bir toplum bilimi olarak tiyatro, dönemini yansitmaktadır. Rönesans'ta aydınlanmanın bir gereği olarak bu sanatın itibar kazanması ve yeni kapılar aralanması da bu durumun bir göstergesidir.

Tiyatroyla sunulan oyunun malzemesi hayattır. Anlatım aracı da insandır. Ya da insanı imleyen figürlerdir. Somut gerçeğe diğer sanat dallarından daha bağımlı olması da bu yüzdendir. Hayatın canlandırılması yani yaşamın estetize edilerek sunulması, gerçeği kurgusal gerçeğe dönüştürerek -hayat gerçeğini değiştirmese de bir oyun olarak kalsa da- yaşamı yansıtması bakımından eleştirel bir ayna vazifesi görmektedir. Bir bakıma hayat oyunu, tiyatro oyunuyla bozuma uğrayarak yaşam gerçeği tüm çıplaklığıyla ortaya dökülmektedir. Bu durum ise yeni bakış açıları, değerlendirmeler, eleştirel yaklaşımlar kısaca sorgulamalar getirmektedir. Dolayısıyla da bir takım kişi, grup, inanç sistemi, siyasi erk gibi toplumu dizayn edenler bu durumdan rahatsı olabilmektedir.

Tüm bunların üstesinden gelebilmek için, oyunculuk mesleğinin ontolojisine sadık kalınarak, tiyatronun bir toplum bilimi olduğunu, oyunculuğun da bu bilimin çerçevesinde oluştuğunu ve hayatın birebir yansıma değil, sanatçıya özgü dünya görüşüyle yeniden yaratılması anlamına geldiğini her platformda farklı çalışmalarlarla yinelemek gerekmektedir. 


\section{KAYNAKÇA}

Andiç, B. (2019). Stanislavski Sistemi'nden Hareketle Derviş Zaim'in Devir, Balık Ve Rüya Filmleri Özelinde Sinema Oyunculuğu (Basılmamış Doktora Tezi). Maltepe Üniversitesi İletişim Bilimleri ABD.

Erişim Adresi: https://tez.yok.gov.tr/UlusalTezMerkezi/tezSorguSonucYeni.jsp

Aristoteles. (1987). Poetika. İ. Tunalı (çev.). İstanbul: Remzi Kitapevi.

Baltacıoğlu, İ.H. (2006). Tiyatro Nedir. İstanbul: Mitos Boyut Tiyatro Yayınları.

Bamunusinghe, S. (2012). Drama as a Mode of Communication in the Ancient Greek World, Sri Lankan Journal of Human Resource Management, 3 (1), s78-85.

Brockett, O. G. (2000). Tiyatro Tarihi. Ankara: Dost Kitapevi Yayınları.

Burke, P. (2015). Avrupa'da Rönesans: Merkezler ve Çeperler. U. Abacı (çev.). İstanbul: Islık Yayınları.

Carlson, M. (2007). Tiyatro Teorileri. E. Buğralılar, B. Yıldırım (çev.). Ankara: De Ki BasımYayım.

Carter, D. (2011) Oyunculuk Sanatı ve Bu Sanatta Ustalaşmak. B. Baysal (çev.). İstanbul: Kalkedon Yayınevi.

Cole, T.\& Chinoy, H.K. (1997). Ünlü Oyunculardan Oyunculuk Sanatı 1. M. Balay (çev.). İstanbul: Mitos Boyut Yayınevi.

Coşkun, İ. (2003). Modernliğin Kaynakları: Rönesans Üzerine Bir Değerlendirme. İstanbul Üniversitesi Sosyoloji Dergisi, 3,(6), s.45-70.

Çalışırlar, A. (1995). Tiyatro Ansiklopedisi. Ankara: Türk Tarih Kurumu Basımevi.

Çüçen, A.K. (2006). Batı Aydınlanmasının Düşünsel Kökeni Ve Eleştirisi, Muğla Üni. Sos. Bil. Enst. Dergisi, 83. Y11 Özel Sayıs1, s.25-34.

Doğan, S. (2003). Avrupa'nın Alacakaranlıkta Uçan Baykuşu. Hacettepe Üniversitesi Edebiyat Fakültesi Dergisi, 20(2), s. 73-89.

Fischer, E. (2017). Sanatın Gerekliliği. C. Capan (çev.). İstanbul: Sözcükler Yayınevi.

Freeman, C. (2003). Mısır, Yunan ve Roma: Antik Akdeniz Uygarlıkları S. K. Angı (çev.). Ankara: Dost Kitapevi.

Friedell, E. (1999). Antik Yunan'ın Kültür Tarihi. N. Aça (çev.). Ankara: Dost Yayınevi.

Fuat, M. (2010). Tiyatro Tarihi. İstanbul: MSM Yayınları.

Gerçek, S.N. (1944). Tiyatro Bilgisi. (Basım yeri belirtilmemiş) : Türkiye Yayınevi.

Hornby, R. (1983). Understanding Acting, The Journal of Aesthetic Education, 17(3), s. 19-37.

Haigh, A. E. (1889). The Attic Theatre: A Description of the Stage and Theatre of the Athenians, and of the Dramatic Performances at Athens. Oxford: At The Calerendon Press.

Hançerlioğlu, O. (1967). Felsefe Sözlüğü. İstanbul: Remzi Kitabevi.

Huizinga, J. (2013). Homo Ludens. M. A. Kılıçbay (çev.). İstanbul: Ayrıntı Yayınları. 
Kagan, M. (1982). Güzellik Bilimi Olarak Estetik ve Sanat. A.Çalışlar (çev.). Altınkitaplar Yayınevi.

Karakoç, E. ( 2015). Antik Roma'da Kadın Gladyatörler. Akademik Bakış Dergisi Uluslararası Sosyal Bilimler E-Dergisi, (52), s.154-161.

Kargı, H. (1991). Antik Çağ Tiyatroları ve Pamphylia'daki Örnekleri. (Basılmamış Yüksek Lisans Tezi). Mimar Sinan Üniversitesi Arkeoloji ve Sanat Tarihi ABD

Erişim Adresi: https://tez.yok.gov.tr/UlusalTezMerkezi/tezSorguSonucYeni.jsp

Kenneth, G.\& Henry G. (1919). Roman Actors, Studies in Philology, 16(4) s.334-382).

Le Goff, J. (1992). Medieval Civilization, Oxford: Blackwell Publishers.

Nietzsche, F. (2019). Tragedya'nın Doğuşu. M. Tüzel (çev.). İstanbul: Türkiye İş Bankası Kültür Yayınları.

Nutku, Ö. (1995). Oyunculuk Tarihi: Başlangıçtan XIX. Yüzyıla. İstanbul: Yapı Kredi Yayınları.

Nutku, Ö. (2001). Tiyatroya Giriş. İstanbul: Kabalcı Yayınevi.

Ogilvy, J.D.A (1963). Mimi, Scurrae, Histriones: Entertainers of the Early Middle Ages. Medieval Academy of America. 38(4), s.603-619. https://doi.org/10.2307/2851658.

Öztürk Çetindoğan, M. (2015). Yalan ve Tiyatro. Yedi: Sanat, Tasarım ve Bilim Dergisi. (14), s.117-124.

Platon. (1999). Devlet. S. Eyüpoğlu, M.A Cimcoz (çev.). İstanbul: Türkiye İş Bankası Yayınları.

Pignarre, R. (1991). Tiyatro Tarihi. P.Kür (çev.). İstanbul: İletişim Yayınları.

Schiller. (1990). İnsanın Estetik Eğitimi Üzerine Bir Dizi Mektup. M. Özgü (çev.). Ankara: Milli Eğitim Bakanlığı Yayınları.

Schyberg, F. \& Carlson, G. H. (1961). The Art of Acting. The Tulane Drama Review, 5,(4), s. 56-76.

Sivri, M. \& Ciner, A.(2010). Plautus'un “Amphitryon” Adlı Eseri İle Molière Ve Heinrich Von Kleist Uyarlamalarında Metinleraras1lık. Uluslararası Kıbrı Üni.folklor/edebiyat Dergisi, 16(63), s. 127-154.

Şener, S. (2003). Dünden Bugüne Tiyatro Düşüncesi. Ankara: Dost Yayınevi.

Şener, S. (2006). Dünden Bugüne Tiyatro Düşüncesi. (4. Baskı). Ankara: Dost Yayınevi.

Tekerek, N. (2006). Oyun Kavramı'ndan Drama'ya Drama'dan Dramatik Eğitim'e. Tiyatro Araştırmaları Dergisi. (22), s. 47-73.

Teraman, Ö. (2007). Roma Dönemi Tiyatro-Tapınak Kompleksleri Ve Anadolu'daki İzdüşümleri. (Basılmamış Yüksek Lisans Tezi). Anadolü Üni. Klasik Arkeolji ABD

Erişim Adresi: https://tez.yok.gov.tr/UlusalTezMerkezi/tezSorguSonucYeni.jsp

Thomson, G. (1990). Aiskhylos ve Atina. M.H. Doğan (çev.). İstanbul: Payel Yayınları.

Trentius. ( 1946). Formio. N. Ataç (çev). Ankara: MEB Yayınları. 
Uzunaslan, A. (2005). Antik Roma"eda Gladyatör Oyunları. Süleyman Demirel Üniversitesi FenEdebiyat Fakültesi Sosyal Bilimler Dergisi. (12), s.15-58.

Vicentini, C. (2012). Theory of Acting- From Antiquity to the Eighteenth Century. Napoli: Marsilio\&Acting Archives .

Wasson, J. (1984). Professional Actors in the Middle Ages and Early Renaissance Medieval \& Renaissance Drama in England, 1, s.1-11.

Y1ldırım, M.S. (2013). Experiencing The Ancient Theatre: A Perspective On Interpreting The Ancient Greek And Roman Theatre Through Reflections From The Space Of The Performer. (Basılmamış Yüksek Lisans Tezi). The Department Of History Of Architecture. Middle East Technical University.

Erişim Tarihi:29.04.2021

Erişim Adresi: https://tez.yok.gov.tr/UlusalTezMerkezi/tezSorguSonucYeni.jsp

Yıldırım, E. (2021). Antik Dönem'den Postmodernizm’e Oyun-Gerçek Paradoksu ve Aktörlük.

(Basılmamış Doktora Tezi). Maltepe Üniversitesi İletişim Bilimleri ABD.

Erişim Tarihi: 01.03.2021

Erişim Adresi: https://tez.yok.gov.tr/UlusalTezMerkezi/tezSorguSonucYeni.jsp

Ziss, A. (1984). Estetik. Y. Şahan (çev.). İstanbul: DE Yayınevi. 